University of Nebraska - Lincoln

DigitalCommons@University of Nebraska - Lincoln

\title{
A Modified Molybdenum Blue Method for Orthophosphate Determination Suitable for Investigating Enzymatic Hydrolysis of Organic Phosphates
}

\author{
Zhongqi He \\ United States Department of Agriculture-Agricultural Research Service, Zhongqi.He@ars.usda.gov \\ C. Wayne Honeycutt \\ USDA-ARS
}

Follow this and additional works at: https://digitalcommons.unl.edu/usdaarsfacpub

Part of the Agricultural Science Commons

He, Zhongqi and Honeycutt, C. Wayne, "A Modified Molybdenum Blue Method for Orthophosphate Determination Suitable for Investigating Enzymatic Hydrolysis of Organic Phosphates" (2005).

Publications from USDA-ARS / UNL Faculty. 536.

https://digitalcommons.unl.edu/usdaarsfacpub/536

This Article is brought to you for free and open access by the U.S. Department of Agriculture: Agricultural Research Service, Lincoln, Nebraska at DigitalCommons@University of Nebraska - Lincoln. It has been accepted for inclusion in Publications from USDA-ARS / UNL Faculty by an authorized administrator of DigitalCommons@University of Nebraska - Lincoln. 


\title{
A Modified Molybdenum Blue Method for Orthophosphate Determination Suitable for Investigating Enzymatic Hydrolysis of Organic Phosphates
}

\author{
Zhongqi He and C. Wayne Honeycutt \\ USDA-ARS, New England Plant, Soil, and Water Laboratory, University \\ of Maine, Orono, Maine, USA
}

\begin{abstract}
In characterizing organic phosphorus $\left(\mathrm{P}_{\mathrm{o}}\right)$ by phosphatase hydrolysis, the quantity of hydrolyzable $\mathrm{P}_{\mathrm{o}}$ is represented by the difference in orthophosphate [i.e., inorganic $\mathrm{P}\left(\mathrm{P}_{\mathrm{i}}\right)$ ] determined after and prior to enzymatic incubation. Therefore, precise determination of $\mathrm{P}_{\mathrm{i}}$ is of major importance for accurate application of the enzymatic hydrolysis approach. The strong acid conditions required for conventional molybdenum blue methods interferes with $\mathrm{P}_{\mathrm{i}}$ determination due to rapid hydrolysis of labile $\mathrm{P}_{\mathrm{o}}$ and precipitation of enzymes (proteins). The molybdenum blue method of Dick and Tabatabai in 1977 reduced errors pertaining to nonenzymatic hydrolysis of $\mathrm{P}_{\mathrm{o}}$. This study revisited the method, finding that the absorption coefficient at $850 \mathrm{~nm}$ was $45-49 \%$ higher than at $700 \mathrm{~nm}$, and linear up to at least $80 \mathrm{nmol} \mathrm{P}_{\mathrm{i}}$ in 1 -mL assay solution. Therefore, adaptation of the readings at $850 \mathrm{~nm}$ improved the sensitivities of $\mathrm{P}_{\mathrm{i}}$ determination by about 45\%. Enzyme precipitation during $\mathrm{P}_{\mathrm{i}}$ determination was prevented by addition of $2 \%$ sodium dodecyl sulfate (SDS) before color-forming reagents were added. This method modification provides increased sensitivity for $\mathrm{P}_{\mathrm{i}}$ determination, thereby improving the accuracy of $\mathrm{P}_{\mathrm{o}}$ analysis by phosphatase hydrolysis.
\end{abstract}

Keywords: Ascorbic acid method, molybdenum blue method, organic phosphorus, phosphorus determination, sodium dodecyl sulfate

Received 6 January 2004, Accepted 20 August 2004

Address correspondence to Zhongqi He, USDA-ARS, New England Plant, Soil, and Water Laboratory, University of Maine, Orono, ME 04469, USA. E-mail: zhongqi. he@ars.usda.gov 


\section{INTRODUCTION}

Perhaps the most commonly used method to determine inorganic orthophosphate $\left(\mathrm{P}_{\mathrm{i}}\right)$ is the spectrophotometric molybdenum blue method. The assay procedure used in agricultural and environmental analyses generally follows that reported by Murphy and Riley (1962) and Watanabe and Olsen (1965). It involves the reaction of acid ammonium molybdate with $\mathrm{P}_{\mathrm{i}}$ ions to form phosphomolybdenum complexes, which are reduced to molybdenum blue by ascorbic acid. However, it is known that the assay conditions used can cause partial hydrolysis of some labile organic phosphate $\left(\mathrm{P}_{\mathrm{o}}\right)$ and condensed $\mathrm{P}_{\mathrm{i}}$, resulting in overestimation of $\mathrm{P}_{\mathrm{i}}$ (Lowry and Lopez 1946; Dick and Tabatabai 1977; Tarapchak 1983). Partly because of this reason, "molybdate reactive P" has been proposed to describe the P determined by the Murphy-Riley method (Ron Vaz et al. 1993; Haygarth and Sharpley 2000). This operational definition only superficially improves the method. Errors associated from the time-dependent nature of labile $\mathrm{P}$ hydrolysis are not corrected, giving rise to the progressive increase of the blue color intensity (Dick and Tabatabai 1977).

Although acceptable for P determination in most agricultural and environmental studies, the Murphy-Riley method is not suitable for studies requiring sensitive $\mathrm{P}_{\mathrm{i}}$ determination. One adaption of the method is a change in assay conditions to a mild acid buffer at $\mathrm{pH} 4$ or 5 , thus reducing the rate of labile $\mathrm{P}_{\mathrm{o}}$ hydrolysis (Lowry and Lopez 1946; Saheki, Takeda, and Shimazu 1985). This approach has been used in assays of enzymatically $P_{i}$-releasing reactions from labile $\mathrm{P}_{\mathrm{o}}$ substrates in biochemical research (Saheki, Takeda, and Shimazu 1985; Drueckes, Schinzel, and Palm 1995). However, the method appears unsuitable for complex agricultural and environmental samples due to the interference of silicate and other impurities (Lowry and Lopez 1946; Saheki, Takeda, and Shimazu 1985). Dick and Tabatabai (1977) reduced errors by complexing the excess molybdate ions to prevent further formation of blue color from $\mathrm{P}_{\mathrm{i}}$ derived from acid labile $\mathrm{P}$ hydrolysis. In their method, molybdenum blue color is rapidly formed by the reaction of $\mathrm{P}_{\mathrm{i}}$ with molybdate ions in the presence of ascorbic acid-trichloroacetic acid; and citrate-arsenite reagents were subsequently added. Any $P_{i}$ arising from hydrolysis of $\mathrm{P}_{\mathrm{o}}$ and condensed $\mathrm{P}_{\mathrm{i}}$ after that cannot react with molybdenum, which has complexed with citrate-arsenite. This method improves the accuracy of $P_{i}$ determination in soil samples (Dick and Tabatabai 1977; Kuo 1996).

Phosphatase hydrolysis has emerged as a useful tool to characterize soluble $\mathrm{P}_{\mathrm{o}}$ from various sources (He and Honeycutt 2001; He, Honeycutt, and Griffin 2003; Pant and Warman 2000; Shand and Smith 1997; Turner, McKelvie, and Haygarth 2002). In these studies, enzymatically hydrolyzable $\mathrm{P}_{\mathrm{o}}$ in a given sample is calculated as the difference between $\mathrm{P}_{\mathrm{i}}$ contents determined in the presence and absence of enzyme(s). Thus, reducing chemical hydrolysis of labile $\mathrm{P}_{\mathrm{o}}$ that occurs during $\mathrm{P}_{\mathrm{i}}$ determination will make a 
significant contribution to accuracy of enzymatic characterization. Another concern is interference by protein precipitates under the acidic conditions for $\mathrm{P}_{\mathrm{i}}$ determination (He and Honeycutt 2001; Shand and Smith 1997; Pant, Vaughan, and Edwards 1994). One way to reduce protein interference is to keep the enzyme concentrations low (He and Honeycutt 2001; Turner, McKelvie, and Haygarth 2002). However, reducing enzyme concentrations may lead to incomplete hydrolysis of relevant hydrolyzable organic $\mathrm{P}$ compounds, especially in the case of high $\mathrm{P}_{\mathrm{i}}$ concentrations, which inhibit phosphatase activities (Juma and Tabatabai 1978). Shand and Smith (1997) reduced interference by addition of dimethyl sulphoxide in the assay solution. However, $40 \%(\mathrm{v} / \mathrm{v})$ of the additive was required for rapid dissolution of the precipitates, and the absorbance peak was shifted from 882 to $890 \mathrm{~nm}$. In this work, the Shand and Smith (1997) method was revisited, finding a higher absorption peak at $850 \mathrm{~nm}$ in addition to the reported peak at $700 \mathrm{~nm}$. The efficacy of sodium dodecyl sulfate (SDS) was examined for eliminating interference of protein precipitation on $\mathrm{P}_{\mathrm{i}}$ determination.

\section{MATERIALS AND METHODS}

\section{Reagents}

All chemicals used were of reagent grade and commercially available. All reagents were prepared with deionized water.

Reagents for color reactions were prepared on the basis of the work of Dick and Tabatabai (1977). For convenience and completeness, the reagents and procedures follow:

- Reagent A: ascorbic acid $(0.1 M)$ and trichloroacetic acid $(0.5 M)$ prepared daily. Dissolve $0.704 \mathrm{~g}$ of ascorbic acid (MW 176.1) and $3.268 \mathrm{~g}$ of trichloroacetic acid (MW 163.4) in about $10 \mathrm{~mL}$ water and adjust the volume to $40 \mathrm{~mL}$.

- Reagent B: ammonium molybdate $(0.01 \quad M)$. Dissolve $2.472 \mathrm{~g}$ of ammonium molybdate (MW 1235.9) in about $100 \mathrm{~mL}$ of water and adjust the volume to $200 \mathrm{~mL}$.

- Reagent C (toxic): sodium citrate $(0.1 \mathrm{M})$, sodium arsenite $(0.2 \mathrm{M})$, and acetic acid (5\%). Dissolve $5.882 \mathrm{~g}$ of sodium citrate (MW 294.12) and $5.196 \mathrm{~g}$ of sodium arsenite (toxic, MW 129.9) in about $100 \mathrm{~mL}$, add $10 \mathrm{~mL}$ of glacial acetic acid, and adjust the volume to $200 \mathrm{~mL}$.

\section{Orthophosphate Determination Procedure}

The procedure reported by Dick and Tabatabai (1977) was followed. However, the total assay volume was reduced to $1 \mathrm{~mL}$ from $25 \mathrm{~mL}$ in the original report. The volumes of samples and reagents were reduced 
accordingly. Specifically, to $0.32-\mathrm{mL}$ of samples and buffer/water, $0.40 \mathrm{~mL}$ of reagent $\mathrm{A}, 0.08 \mathrm{~mL}$ of reagent $\mathrm{B}$, and $0.20 \mathrm{~mL}$ of reagent $\mathrm{C}$ were added sequentially. The solutions were stirred thoroughly with a cuvette stirring rod after the addition of each reagent. The absorbance of the molybdenum blue was recorded over time or read at $850 \mathrm{~nm}$ and/or $700 \mathrm{~nm}$ after 30 min. Alternatively, $0.10 \mathrm{~mL}$ of $20 \%$ SDS was added prior to reagent A. In such case, the assay volume totaled $1.1 \mathrm{~mL}$. Total $\mathrm{P}$ in the water extracts of a swine manure was determined in the same way after persulfate digestion of $1 / 8$ diluted extracts (Rowland and Haygarth 1997). The proteins used were the combinations of acid phosphatases, type I from wheat germ (0.5 $\mathrm{U} \mathrm{mg}^{-1}$ solid) and type IV-S from potato (5.3 $\mathrm{U} \mathrm{mg}^{-1}$ solid), and nuclease P1 from Penicillium citrinum (355 $\mathrm{U} \mathrm{mg}^{-1}$ solid) (Sigma, St. Louis, MO) with a ratio of 1:1:6 to their respective activity in order.

\section{Instruments}

An HP $8453 \mathrm{UV} /$ visible spectrophotometer with diode array detectors (Agilent Technologies, Wilmington, DE) was used to record the spectra of the blue phosphomolybdenum complexes. A Spectronic $601 \mathrm{UV} /$ visible spectrophotometer (Milton Roy Company, Rochester, NY) was used routinely to measure absorbance at 850 and $700 \mathrm{~nm}$.

\section{Enzymatic Hydrolysis of $P_{o}$ in Swine Manure}

Freeze-dried swine manure $(0.25 \mathrm{~g}$ each in triplicate) was autoclaved for $1 \mathrm{~h}$ and extracted by $25 \mathrm{~mL}$ of deionized $\mathrm{H}_{2} \mathrm{O}$ for $1 \mathrm{~h}$ at $22^{\circ} \mathrm{C}$ on an orbital shaker $\left(250 \mathrm{r} \mathrm{min}^{-1}\right)$. The samples were then centrifuged at $23,700 \times g$ for $30 \mathrm{~min}$ at $4{ }^{\circ} \mathrm{C}$, and the supernatant was decanted and filtered through a $0.45-\mu \mathrm{m}$ filter. The supernatant (extract) was dispensed in 15-mL tubes $1 \mathrm{~mL}$ each and stored at $-20^{\circ} \mathrm{C}$ until use. For incubation experiments, the extract was diluted to one-half, one-fourth, or one-eighth fold and adjusted to $\mathrm{pH} 5.0$ in $100 \mathrm{~m} M$ sodium acetate buffer. Combinations of acid phosphatases from potato and wheat germ and nuclease P1 were used to release hydrolysable $\mathrm{P}_{\mathrm{o}}$ in the diluted extracts as detailed by $\mathrm{He}$ et al. (2004). The reaction mixtures were incubated at $37^{\circ} \mathrm{C}$; and 50,100 , or $200 \mu \mathrm{L}$ were taken off at various time intervals for $\mathrm{P}_{\mathrm{i}}$ determination. Duplicate incubation was conducted for each triplicate extract.

\section{RESULTS AND DISCUSSION}

\section{Absorption Spectra of Blue Phosphomolybdenum Complexes}

The change in absorption spectra of the blue phosphomolybdenum complexes over incubation time is shown in Figure 1. Two absorbance peaks were observed: one at $700 \mathrm{~nm}$ and another at $850 \mathrm{~nm}$. Dick and Tabatabai (1977) 


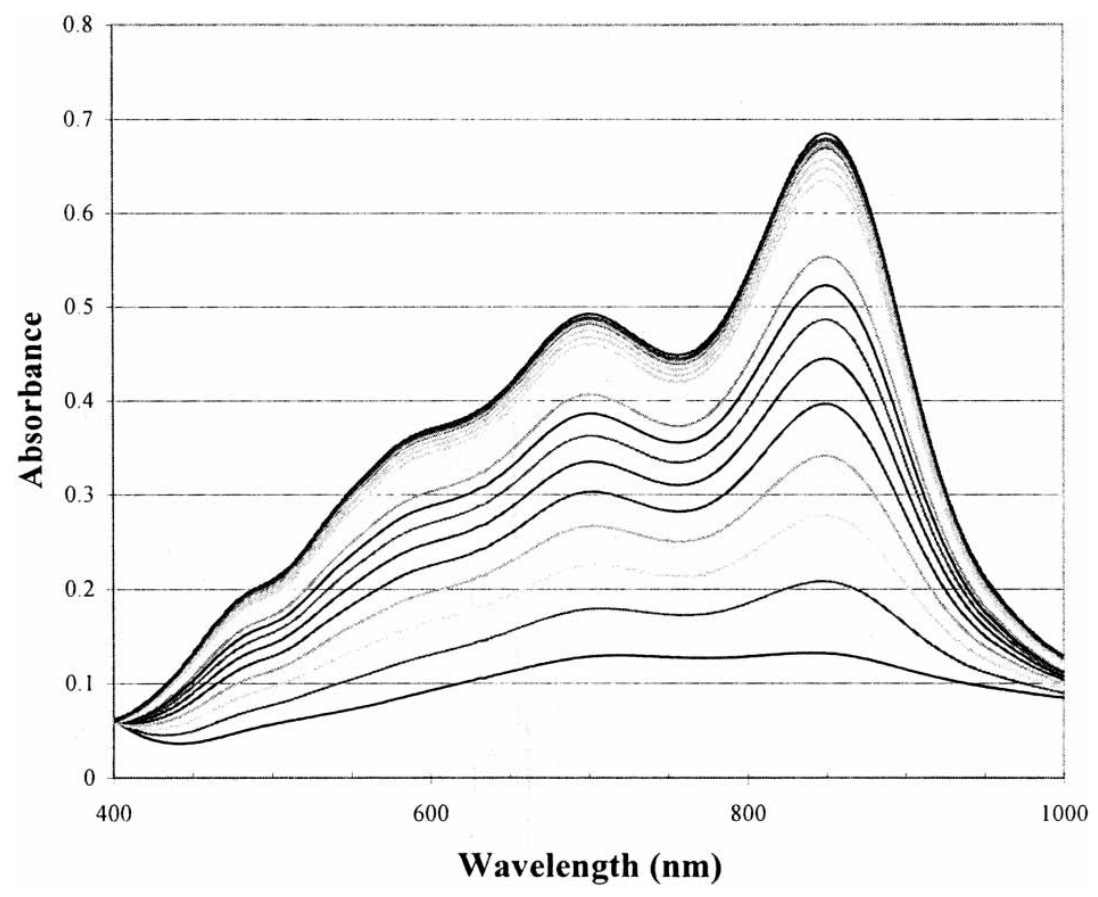

Figure 1. Absorption spectra of the phosphomolybdenum blue complexes. The reaction mixture contained $30 \mathrm{nmol} \mathrm{P}_{\mathrm{i}}$. Recording began immediately after Reagent $\mathrm{C}$ was added with 1-min intervals for a total of $75 \mathrm{~min}$.

did not observe a peak at $850 \mathrm{~nm}$ but a weaker peak at $790 \mathrm{~nm}$. The spectra recorded in this study, however, are basically the same as that reported by Baginski and Zak (1960) who found peaks at $700 \mathrm{~nm}$ and $840 \mathrm{~nm}$. Dick and Tabatabai (1977) used a Beckman DB-G spectrophotometer. Baginski and Zak (1960) used a Coleman Jr. spectrophotometer. We used a HP8453 spectrophotometer with diode array detectors. When we further measured absorbance with a Spectronic $601 \mathrm{UV} /$ visible spectrophotometer, we still observed the peak at $850 \mathrm{~nm}, 43 \%$ higher than that at $700 \mathrm{~nm}$. Because of the same reagents and procedure applied, the difference observed by Dick and Tabatabai (1977) may be associated with an instrument limitation.

\section{Elimination of Protein Interference by SDS}

The enzymes (proteins) used in phosphorylation/dephosphorylation could interfere with $\mathrm{P}_{\mathrm{i}}$ determination by a molybdenum blue method. In the worst case, a blue precipitate may eventually form, causing the supernatant to become virtually colorless (Shand and Smith 1997). Shand and Smith (1997) found that addition of Triton X-100 after formation of the precipitate 
provided a single phase, but the spectral characteristic changed over time. They found addition of $40 \%$ dimethyl sulfoxide to the assaying solution after precipitate formation gave spectra similar to that described by Murphy and Riley (1962) and was stable for at least $20 \mathrm{~min}$. In this work, we tested the alternative addition of SDS prior to color formation to prevent proteins from precipitating, as used in biochemical phosphorylation studies (Saheki, Takeda, and Shimazu 1985; Drueckes, Schinzel, and Palm 1995).

Addition of $0.2 \%$ (final concentration) SDS did not change the spectra of blue phosphomolybdenum complexes over $75 \mathrm{~min}$ (data not shown). As in Figure 2, $39 \mu \mathrm{g}$ of proteins in the assay solution interfered with the absorbance readings at either $700 \mathrm{~nm}$ or $850 \mathrm{~nm}$. In the presence of SDS, however, the
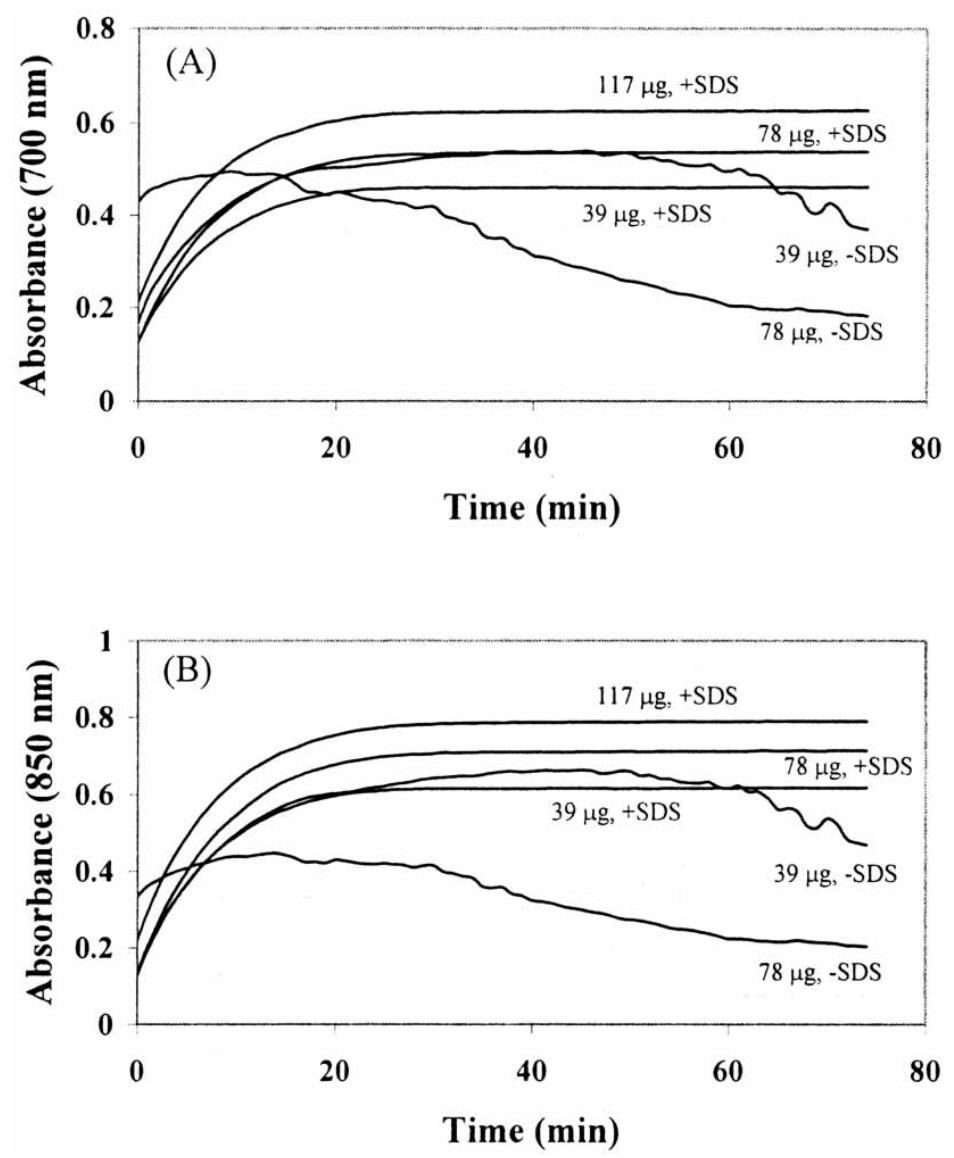

Figure 2. Elimination of the interference of protein precipitation on absorbance readings at $700 \mathrm{~nm}(\mathrm{~A})$ and $850 \mathrm{~nm}$ (B) by $0.1 \mathrm{~mL}$ of $20 \%$ SDS in $1 \mathrm{~mL}$ of assay mixtures (+SDS) with controls ( - SDS). All reaction mixtures contained $30 \mathrm{nmol} \mathrm{P}_{\mathrm{i}}$. Recording began immediately after Reagent $C$ was added for a total of $75 \mathrm{~min}$. Water was used for background zeroing. 
readings were stable even though the protein concentration was as high as $117 \mu \mathrm{g}$. A longer time (30 min), compared to the $10 \mathrm{~min}$ reported in the original report in the absence of SDS (Dick and Tabatabai 1977), was required before a constant color intensity was attained.

\section{Linearity of Standard Curves}

Although absorbance at $700 \mathrm{~nm}$ has been recommended for $\mathrm{P}_{\mathrm{i}}$ determination, measurement at $850 \mathrm{~nm}$ implied improved detection limit and sensitivity, which are especially important for samples where hydrolyzable $\mathrm{P}_{\mathrm{o}}$ is much lower than $\mathrm{P}_{\mathrm{i}}$. In the tested range of $\mathrm{P}_{\mathrm{i}}(5-80 \mathrm{nmol})$, the standard curves at $700 \mathrm{~nm}$ and $850 \mathrm{~nm}$ were both linear (Figure 3). Therefore, absorbance at $850 \mathrm{~nm}$ was suitable to use for $\mathrm{P}_{\mathrm{i}}$ determination. When SDS was included in the assay solution, linearity was not changed. Slopes of the curves made from absorbance at $850 \mathrm{~nm}$ were $45-49 \%$ higher than those at $700 \mathrm{~nm}$. In other words, adaptation of the readings at $850 \mathrm{~nm}$ could improve $\mathrm{P}_{\mathrm{i}}$ determination sensitivity by about $45 \%$.

\section{Hydrolyzable $P_{o}$ in Swine Manure}

This study applied the modified molybdenum blue method to determine enzymatically hydrolyzable $\mathrm{P}_{\mathrm{o}}$ in the water extract of a swine manure. The extract

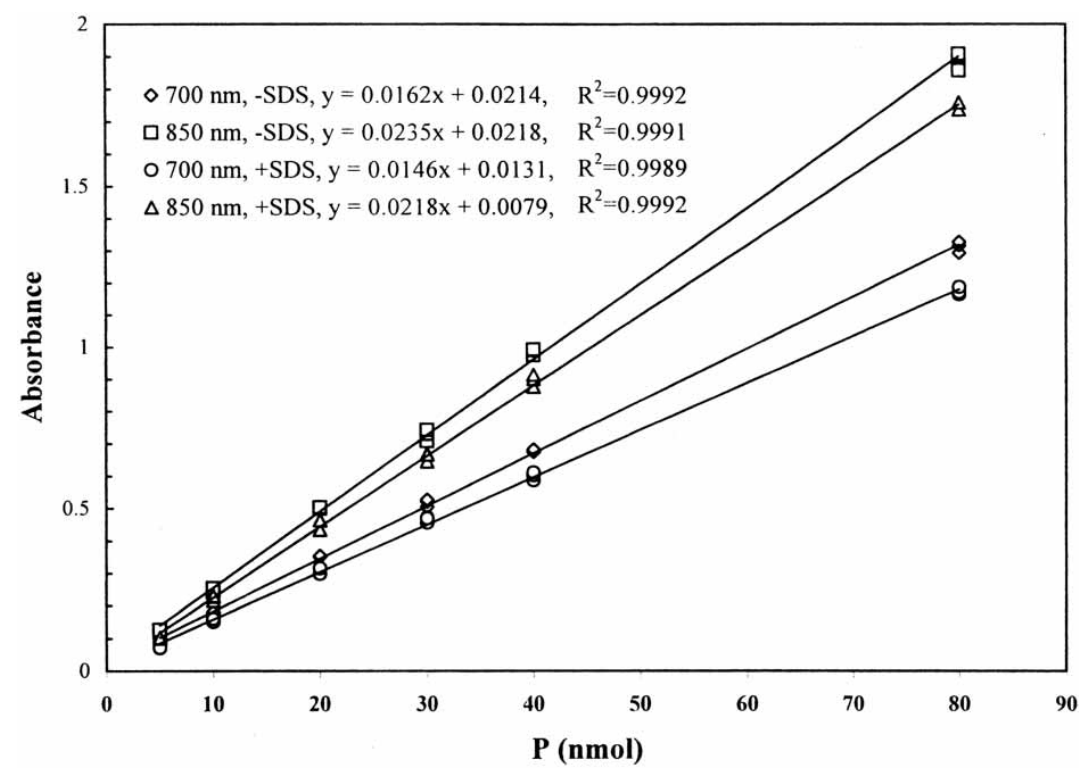

Figure 3. Linear regression of the absorbance at $700 \mathrm{~nm}$ and $850 \mathrm{~nm}$ in the absence $(-)$ and presence $(+)$ of SDS. 
contained $2068 \mathrm{mg}$ total $\mathrm{P} \mathrm{kg}^{-1}$ dry matter (DM) and $1177 \mathrm{mg} \mathrm{P}_{\mathrm{i}} \mathrm{kg}^{-1} \mathrm{DM}$, thus $891 \mathrm{mg} \mathrm{P}_{\mathrm{o}} \mathrm{kg}^{-1} \mathrm{DM}$. The effect of indigenous $\mathrm{P}_{\mathrm{i}}$ in the extracts on $\mathrm{P}_{\mathrm{o}}$ hydrolysis was tested first. When one-half, one-fourth, and one-eighth diluted extracts (i.e., $\sim 10-2.6 \mathrm{mg}_{\mathrm{i}} \mathrm{mL}^{-1}$ of the reaction mixture) were incubated, respectively, with the combination of acid phosphatases from potato and wheat germ and nuclease P1 $\left(0.25,0.25\right.$, and $4.0 \mathrm{U} \mathrm{mL}^{-1}$ of reaction mixture, respectively) for $1 \mathrm{~h}$ at $37^{\circ} \mathrm{C}$, the $\mathrm{P}_{\mathrm{i}}$ determined was $1587 \pm 80,1585 \pm 78$, and $1536 \pm 59 \mathrm{mg} \mathrm{kg}^{-1} \mathrm{DM}$ (average \pm standard deviation). Although $\mathrm{P}_{\mathrm{i}}$ and other metal elements could inhibit the phosphatases activities (Dick and Tabatabai 1984; Juma and Tabatabai 1977), no substantial difference in $\mathrm{P}_{\mathrm{o}}$ concentrations indicated their levels in manure extracts did not affect completeness of $\mathrm{P}_{\mathrm{o}}$ hydrolysis.

The effect of enzyme concentrations on degree of $\mathrm{P}_{\mathrm{o}}$ hydrolysis was then investigated over 6-h incubation. Incubation of the extract at $37^{\circ} \mathrm{C}$ with sodium acetate buffer alone resulted in partial $\mathrm{P}_{\mathrm{o}}$ hydrolysis with an $8 \%$ increase in $\mathrm{P}_{\mathrm{i}}$ (Figure 4). Addition of the enzyme combinations led to rapid release of hydrolyzable $\mathrm{P}_{\mathrm{o}}$. The $\mathrm{P}_{\mathrm{i}}$ concentration reached a lower plateau within $2 \mathrm{~h}$ with $\mathrm{C} 1$. These data indicated that a sufficient amount of enzymes should be supplied to avoid an underestimation of hydrolyzable $\mathrm{P}_{\mathrm{o}}$. The $\mathrm{P}_{\mathrm{i}}$ average measured from 1 to $6 \mathrm{~h}$ with $\mathrm{C} 2, \mathrm{C} 3$, and $\mathrm{C} 4$ was

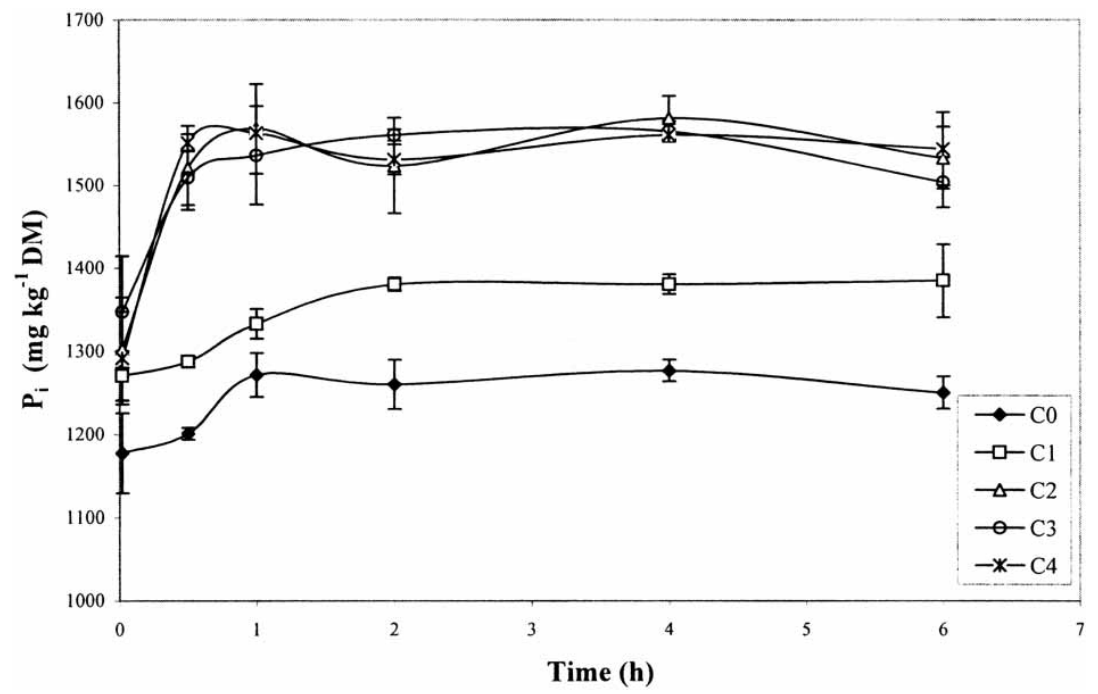

Figure 4. Time course of release of hydrolyzable $\mathrm{P}_{\mathrm{o}}$ in the water extracts of a swine manure by enzyme hydrolysis. Combinations of acid phosphatases from potato and wheat germ and nuclease $\mathrm{P} 1$ with their respective activities $\left(\mathrm{U} \mathrm{mL}^{-1}\right.$ of reaction mixture) in order: 0-0-0 (C0), 0.01-0.01-0.06 (C1), 0.1-0.1-0.6 (C2), 0.25-0.25-4.0 (C3), and 0.75-0.75-12 (C4) were used to release hydrolyzable $\mathrm{P}_{\mathrm{o}}$ in the one-eighth diluted extracts. $\mathrm{P}_{\mathrm{i}}$ was determined with inclusion of SDS. 
Table 1. Average (A) and standard deviation of $\mathrm{P}_{\mathrm{i}}\left(\mathrm{mg} \mathrm{kg}^{-1}\right.$ dry matter) determined with $(+)$ and without $(-)$ SDS $6 \mathrm{~h}$ after incubation of one-eighth diluted extracts of swine manure with $\mathrm{P}_{\mathrm{i}}$-releasing enzymes (six replications)

\begin{tabular}{lrrrrr}
\hline & $\mathrm{C}^{a}$ & $\mathrm{C} 1$ & $\mathrm{C} 2$ & $\mathrm{C} 3$ & $\mathrm{C} 4$ \\
\hline+ SDS & & & & & \\
A & 1250 & 1345 & 1525 & 1503 & 1544 \\
SD & 22 & 43 & 34 & 41 & 64 \\
- SDS & & & & & \\
A & 1223 & 1347 & 1508 & 1519 & $1074^{b}$ \\
SD & 70 & 45 & 32 & 82 & 195 \\
\hline
\end{tabular}

${ }^{a}$ Combinations of acid phosphatases from potato and wheat germ and nuclease $\mathrm{P} 1$ with their respective activities $\left(\mathrm{U} \mathrm{mL}^{-1}\right.$ of reaction mixture) in order: 0-0-0 (C0), 0.01-0.01-0.06 (C1), 0.1-0.1-0.6 (C2), 0.25-0.25-4.0 (C3), and 0.75-0.75-12 (C4) were used.

${ }^{b}$ Precipitate in the assay solution was observed.

$1548 \mathrm{mg} \mathrm{kg}^{-1} \mathrm{DM}$ with a standard deviation of 23. By subtracting $1177 \mathrm{mg}$ initial $\mathrm{P}_{\mathrm{i}} \mathrm{kg}^{-1} \mathrm{DM}$, this represented $371 \mathrm{mg}$ hydrolyzable $\mathrm{P}_{\mathrm{o}} \mathrm{kg}^{-1} \mathrm{DM}$. Hhydrolyzable $P_{o}$ was $42 \%$ of total soluble $P_{o}$ in the swine manure.

At the end of the incubation, $\mathrm{P}_{\mathrm{i}}$ was determined with and without the addition of SDS (Table 1). When no or less enzymes were present, the $\mathrm{P}_{\mathrm{i}}$ determined was basically the same whether or not SDS was included. As shown by the lower standard deviations with $\mathrm{C} 3$ and $\mathrm{C} 4$, however, reproducibility of $\mathrm{P}_{\mathrm{i}}$ determination was improved with SDS when higher concentrations of enzymes were used in hydrolysis incubation. Improved accuracy of $\mathrm{P}_{\mathrm{i}}$ determination was more obvious when the precipitates formed in the assay solution (C4 in Table 1). These data indicate that concern over protein interference is reduced by adding SDS.

\section{CONCLUSIONS}

Reassessment of a current method of $\mathrm{P}$ determination revealed an absorbance peak of blue phosphomolybdenum complexes at $850 \mathrm{~nm}$ with a higher absorbance coefficient than at the originally reported $700 \mathrm{~nm}$. The linearity of absorbance at $850 \mathrm{~nm}$ made it possible to improve the sensitivity of $\mathrm{P}_{\mathrm{i}}$ determination by $45 \%$. The higher sensitivity was essential for investigating $\mathrm{P}_{\mathrm{o}}$ by enzymatic hydrolysis in which hydrolyzable $\mathrm{P}_{\mathrm{o}}$ is calculated from the difference of $P_{i}$ determined after incubation in the presence and absence of phosphatases. The interference of protein (enzyme) precipitates during $\mathrm{P}_{\mathrm{i}}$ determination could be eliminated by addition of $0.2 \%$ SDS prior to adding 
the color-forming reagents. Inclusion of SDS removes protein interference so that high enzyme concentrations can be used to ensure all hydrolyzable $\mathrm{P}_{\mathrm{o}}$ is released and accounted for properly.

\section{ACKNOWLEDGMENTS}

Trade or manufacturers' names mentioned in the article are for information only and do not constitute endorsement, recommendation, or exclusion by the USDA-ARS.

\section{REFERENCES}

Baginski, E. and Zak, B. (1960) Micro-determination of serum phosphate and phospholipids. Clinica Chimica Acta, 5: 834-838.

Dick, W.A. and Tabatabai, M.A. (1977) Determination of orthophosphate in aqueous solutions containing labile organic and inorganic phosphorus compounds. Journal of Environmental Quality, 6: 82-85.

Dick, W.A. and Tabatabai, M.A. (1984) Kinetic parameters of phosphatases in soils and organic waste materials. Soil Science, 137: 7-15.

Drueckes, P., Schinzel, R., and Palm, D. (1995) Photometric microtiter assay of inorganic phosphate in the presence of acid-labile organic phosphates. Analytical Biochemistry, 230: 173-177.

Haygarth, P.M. and Sharpley, A.N. (2000) Terminology for phosphorus transfer. Journal of Environmental Quality, 29: 10-15.

He, Z. and Honeycutt, C.W. (2001) Enzymatic characterization of organic phosphorus in animal manure. Journal of Environmental Quality, 30: 1685-1692.

He, Z., Honeycutt, C.W., and Griffin, T.S. (2003) Enzymatic hydrolysis of organic phosphorus in extracts and resuspensions of swine manure and cattle manure. Biology and Fertility of Soils, 38: 78-83.

He, Z., Griffin, T.S., and Honeycutt, C.W. (2004) Enzymatic hydrolysis of organic phosphorus in swine manure and soils. Journal of Environmental Quality, 367-372.

Juma, N.G. and Tabatabai, M.A. (1977) Effects of trace elements on phosphatase activity in soils. Soil Science Society of America Proceedings, 41: 343-346.

Juma, N.G. and Tabatabai, M.A. (1978) Distribution of phosphomonoesterases in soils. Soil Science, 126: 101-108.

Kuo, S. (1996) Phosphorus. In Methods of Soil Analysis. Part 3, Chemical Methods; Sparks, D.L., ed.; SSSA and ASA: Madison, Wisconsin, 869-919.

Lowry, O.H. and Lopez, J.A. (1946) The determination of inorganic phosphate in the presence of labile phosphate esters. Journal of Biological Chemistry, 162: 421-428.

Murphy, J. and Riley, J.P. (1962) A modified single solution method for the determination of phosphate in natural waters. Analytica Chimia Acta, 27: 31-36.

Pant, H.K. and Warman, P.R. (2000) Enzymatic hydrolysis of soil organic phosphorus by immobilized phosphatases. Biology and Fertility of Soils, 30: 306-311.

Pant, H.K., Vaughan, D., and Edwards, A.C. (1994) Molecular size distribution and enzymatic degradation of organic phosphorus in root exudates of spring barley. Biology and Fertility of Soils, 18: 285-290. 
Ron Vaz, M.D., Edwards, A.C., Shand, C.A., and Cresser, M.S. (1993) Phosphorus fractions in soil solution: influence of soil acidity and fertiliser additions. Plant and Soil, 148: 175-183.

Rowland, A.P. and Haygarth, P.M. (1997) Determination of total dissolved phosphorus in soil solutions. Journal of Environmental Quality, 26: 410-415.

Saheki, S., Takeda, A., and Shimazu, T. (1985) Assay of inorganic phosphate in the mild $\mathrm{pH}$ range, suitable for measurement of glycogen phosphorylase activity. Analytical Biochemistry, 148: 277-281.

Shand, C.A. and Smith, S. (1997) Enzymatic release of phosphate from model substrates and $\mathrm{P}$ compounds in soil solution from a peaty podzol. Biology and Fertility of Soils, 24: 183-187.

Tarapchak, S.J. (1983) Soluble reactive phosphorus in lake water: evidence for molybdate enhanced hydrolysis. Journal of Environmental Quality, 12: 105-108.

Turner, B.L., McKelvie, I.D., and Haygarth, P.M. (2002) Characterization of waterextractable soil organic phosphorus by phosphatase hydrolysis. Soil Biology and Biochemisry, 34: 29-37.

Watanabe, F.S. and Olsen, S.R. (1965) Test of an ascorbic acid method for determining phosphorus in water and $\mathrm{N}_{\mathrm{a}} \mathrm{HCO}_{3}$ extracts from soil. Soil Science Society of America Proceedings, 29: 677-678. 